\title{
Retraction Note: p62 improves AD-like pathology by increasing autophagy
}

\author{
A. Caccamo - E. Ferreira - C. Branca · S. Oddo
}

Published online: 11 August 2020

(c) The Author(s) 2020. This article is published with open access

Retraction to: Molecular Psychiatry (2017) 22:856-873

https://doi.org/10.1038/mp.2016.139

published online 30 August 2016

The Editor-in-Chief and publisher have retracted this article [1] after an investigation by Arizona State University concluded that Figs. 1c and $4 \mathrm{a}$ had been manipulated and falsified by one or more of the authors. The Editor-in-Chief therefore no longer has confidence in the validity of the results and conclusions presented in this article.

A. Caccamo, C. Branca and S Oddo agree with this retraction. E. Ferreira has not responded to correspondence related to this retraction.

Open Access This article is licensed under a Creative Commons Attribution 4.0 International License, which permits use, sharing,

adaptation, distribution and reproduction in any medium or format, as long as you give appropriate credit to the original author(s) and the source, provide a link to the Creative Commons license, and indicate if changes were made. The images or other third party material in this article are included in the article's Creative Commons license, unless indicated otherwise in a credit line to the material. If material is not included in the article's Creative Commons license and your intended use is not permitted by statutory regulation or exceeds the permitted use, you will need to obtain permission directly from the copyright holder. To view a copy of this license, visit http://creativecommons. org/licenses/by/4.0/.

\section{Reference}

1. Caccamo A, Ferreira E, Branca C, Oddo S. p62 improves ADlike pathology by increasing autophagy. Mol Psychiatry. 2017;22:865-73. 